\title{
Apoptosis-induced cleavage of keratin 15 and keratin 17 in a human breast epithelial cell line
}

\author{
V Badock ${ }^{1}$, U Steinhusen ${ }^{2}$, K Bommert $^{\star, 2}$, \\ B Wittmann-Liebold ${ }^{1}$ and A Otto ${ }^{1}$ \\ ${ }^{1}$ Department of Protein Chemistry, Max-Delbrück-Center for Molecular \\ Medicine, Robert-Rössle-Str. 10, D-13092 Berlin, Germany \\ 2 Department of Medical Oncology and Tumorimmunology, \\ Robert-Rössle-Str.10, D-13092 Berlin, Germany \\ * Corresponding author: K Bommert, Max-Delbrück-Center for Molecular \\ Medicine, Department of Medical Oncology and Tumorimmunology, \\ Robert-Rössle-Str. 10, D-13092 Berlin, Germany. \\ Tel: ++49-30-94063817; Fax: ++49-30-94063124; \\ e-mail: bommert@mdc-berlin.de
}

Received 7.8.00; revised 2.11.00; accepted 9.11.00 Edited by SJ Martin

\begin{abstract}
Keratin 15 (K15) and keratin 17 (K17) are intermediate filament (IF) type I proteins that are responsible for the mechanical integrity of epithelial cells. By analyzing the human breast epithelial cell line H184A1 before and after induction of apoptosis by high-resolution two-dimensional gel electrophoresis (2-DE) we identified the caspase-mediated cleavage of keratins 15 and 17. After induction of apoptosis three fragments of both K15 and K17 could be observed by $2-D E$. K15 and K17 proteolysis was observed during staurosporineinduced apoptosis and anoikis (anchorage-dependent apoptosis) as well and was shown to be caspase-dependent. By using mass spectrometry we could determine the caspase cleavage sites, one in K15 and two in K17. The sequence VEMD/A at the cleavage site located in the conserved linker region was found in $\mathrm{K} 15$ and $\mathrm{K} 17$. A further cleavage site was identified in the tail region of $\mathrm{K} 17$ with the recognition motif EVQD/G. Cell Death and Differentiation (2001) 8, 308-315.
\end{abstract}

Keywords: apoptosis; epithelial cells; keratin 15; keratin 17; twodimensional gel electrophoresis; caspases

Abbreviations: $\mathrm{ESI}$, electrospray ionization; IF, intermediate filament; JNK, Jun $\mathrm{NH}_{2}$-terminal kinase; $\mathrm{K} 15$, keratin 15 ; $\mathrm{K} 17$, keratin 17; MS/MS, tandem mass spectrometry; polyHEMA, poly(2hydroxyethylmethacrylate); TNFR2, tumor necrosis factor receptor 2; Z-DEVD-fmk, benzyloxycarbonyl-aspartyl-glutamyl-valyl-aspartyl-fluoromethylketone; 2-DE, two-dimensional gel electrophoresis

\section{Introduction}

Keratins are structurally related proteins that form intermediate filaments (IFs) in epithelial cells. Together with actin microfilaments and microtubules intermediate filaments build the cytoskeleton of eukaryotic cells. IF proteins are grouped into five categories: keratins, desmins, vimentin, neurofila- ment (NF) proteins, and glial fibrillary acidic protein (GFAP). IF proteins are expressed in a tissue-specific manner: keratins in epithelial cells, vimentin in mesenchymal cells, desmin in muscle, and neurofilaments in neuronal cells. The largest and most complex group of IF proteins are keratins. At least 20 different keratin proteins have been described $(K 1-K 20)$, that are subdivided into the acidic type I keratins 9-20 and the basic type II keratins 1-8. Keratin filaments assemble as obligate heteropolymers consisting of a $1: 1$ molar ratio of types I and II monomers. Mutation studies in keratins indicate that one function of the keratin network is to maintain the mechanical integrity in epithelial cells and to resist shear stress applied to the cell. ${ }^{1-4}$ Keratin 17 is associated with type II keratin 6 and is normally expressed in the basal cells of complex epithelia but not in stratified or simple epithelia. Mutation in keratin 17 cause pachyonychia congenita type 2 (Jackson-Lawler syndrome), an autosomal dominant disorder characterized by hypertrophic nail dystrophy, multiple pilosebaceous cysts, and hair abnormalities. ${ }^{5,6}$ Keratin 15 has no defined type II partner. It is expressed in the basal keratinocytes of stratified tissue, including the fetal epidermis and fetal nail. ${ }^{7}$ Recently it was shown that keratin 15 can be used as a specific marker for stem cells of the hair-follicle bulge. $^{8}$ Immunostaining for keratin 15 is demonstrated as a useful method for the differential diagnosis between basal cell carcinoma and trichoepithelioma. ${ }^{9,10}$

Normal epithelial cells undergo apoptosis if they lose cell-cell or cell-matrix contact, a process which has been termed anoikis. ${ }^{11-13}$ This anchorage-dependent apoptosis prevents detached epithelial cells from colonizing at inappropriate sites, and is thus essential for maintaining intact tissue organization. IF proteins represent some of the substrates for caspases. Apoptosis-induced cleavage of IF proteins has been shown previously for keratins 18 and $19,{ }^{14-16}$ for lamins B1, B2, lamins $A, C,{ }^{17}$ and vimentin. ${ }^{18}$ The relevance of cleavage in apoptosis is so far unknown.

One critical issue to understand the molecular basis of apoptosis is the identification of caspase substrates and the determination of their biochemical functions. For identification of proteins that are involved in apoptosis we used highresolution two-dimensional gel electrophoresis (2-DE) to separate proteins of a human breast epithelial cell line before and after induction of apoptosis. 2-DE is able to separate up to 10000 proteins and is therefore the favored separation method for proteins in cell lysates. ${ }^{19}$ The silver stained protein pattern of apoptotic and non-apoptotic cells were compared and differentially expressed proteins were identified by mass spectrometric techniques, namely electrospray tandem mass spectrometry (ESI-MS/MS). ${ }^{20}$ Here we show that keratin 15 (K15) and keratin 17 (K17) are specifically cleaved after induction of apoptosis into at least three distinct fragments. We were able to determine some of the cleavage sites in $\mathrm{K} 15$ and $\mathrm{K} 17$ by mass spectrometry. 


\section{Results}

\section{Identification of keratins $\mathbf{1 5}$ and $\mathbf{1 7}$}

In order to identify new proteins, which are associated with apoptosis, we applied high-resolution two-dimensional gel electrophoresis to separate the cell lysate of a human breast epithelial cell line before and after induction of apoptosis. For the induction of apoptosis, cells of the human breast epithelial cell line H184A1 were incubated with staurosporine (STS) or with dimethylsulfoxide (DMSO) as control. Adherent cells and floating cells were collected separately and analyzed by 2-DE. After STS treatment for $20 \mathrm{~h}$ floating cells showed a rate of apoptosis of $89 \%$ whereas the adherent cells showed a rate of $37 \%$. A 2-DE map of the detached apoptotic cells containing approximately 4000 protein spots is shown in Figure 1. Molecular weight (Mw) and isoelectric point ( $\mathrm{pl}$ ) calibration of the gels was done by using the calculated values of identified proteins taken from the SwissProt database. By visual comparison of the 2-DE protein pattern of non-apoptotic and apoptotic epithelial cells we identified several protein spots which appear or showed a significantly altered intensity. The mass spectrometric identification revealed proteins such as lamin $A$ and $C,{ }^{17}$ hnRNPs, $^{21}$ and keratin $18^{14}$ which were already described previously as being caspase substrates.

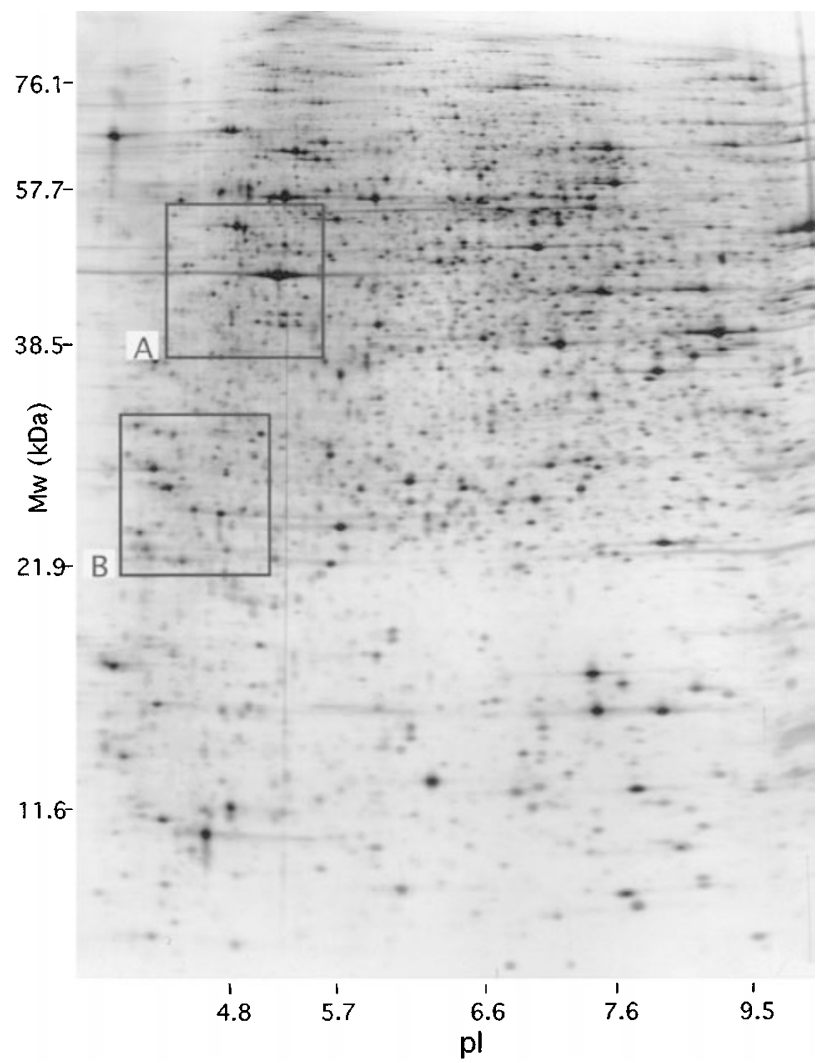

Figure 1 Gel image of whole cell lysate of apoptotic H184A1 cells separated by high-resolution two-dimensional gel electrophoresis. Calibration of molecular weight $(\mathrm{Mw})$ and isoelectric point $(\mathrm{pl})$ was performed as described in Materials and Methods. ( $A$ and $\mathbf{B}$ ) Regions of differently expressed proteins after induction of apoptosis are indicated, and are shown in more detail in Figure 2A,B
Furthermore, we could observe the disappearance of two spots in the apoptotic gel that turned out to be keratins 15 and 17 (Figure 2A). Simultaneously, six new spots appeared in the same gel with molecular masses ranging from approximately $20-27 \mathrm{kDa}$. They were identified as fragments of keratins 15 and 17 , three of the six spots $(\mathrm{P} 1-\mathrm{P} 3)$ belonged to $\mathrm{K} 15$ and three (P4-P6) to $\mathrm{K} 17$ suggesting that both, $\mathrm{K} 15$ and $\mathrm{K} 17$ are cleaved into at least three distinct fragments during apoptosis (Figure 2B). In addition, we observed the same cleavage pattern using a more physiological stimulus to induce apoptosis in epithelial cells which is termed anoikis. For this reason we kept cells for $24 \mathrm{~h}$ in suspension by cultivating them on polyHEMA coated plates (data not shown).

\section{Caspase-specific cleavage of keratins 15 and 17 during apoptosis}

To determine if this fragmentation is induced by caspases, we performed 2-DE of cell lysates, which were treated with ZDEVD-fmk, an inhibitor for caspase-3-like proteases prior to STS induced apoptosis. Z-DEVD-fmk completely blocks the disappearance of full-length keratins 15 and 17 (Figure 2A,III) and the appearance of spots P1-P6 (Figure 2B,III), respectively. These observations lead to the conclusion that K15 and K17 were cleaved during apoptosis by caspase-3like proteases or caspases activated downstream of caspase3. The cleavage of $\mathrm{K} 17$ during apoptosis can also be observed by Western blot analysis. Lysates from adherent cells after STS treatment, cells pretreated with caspase inhibitors as indicated, and cells treated with $0.2 \%$ DMSO as control were separated by SDS-PAGE. As shown in Figure 3 , non-apoptotic cells only show full-length $\mathrm{K} 17$ whereas in the cell lysate from adherent cells after staurosporine treatment one fragment (A) could be detected with the monoclonal $\mathrm{K} 17$ antibody. The appearance of fragment $\mathrm{A}$ could be blocked by caspase inhibitors Z-DEVD-fmk. In addition cleavage of keratin 15 was analyzed by an in vitro cleavage assay. Therefore, $\mathrm{K} 15$ was translated using a TNT reticulocyte lysate system in the presence of ${ }^{35} \mathrm{~S}$-methionine and incubated with recombinant caspases-2, $-3,-6,-7,-8$, and -9. Figure 4 shows that caspase- 6 cleaves K15 into three fragments with high efficiency, while caspases-3 and -7 removed only a small fragment $(\mathrm{Px})$ presumeably the $\mathrm{C}$ terminus of full-length keratin 15.

\section{Mapping the keratin cleavage sites}

Caspase-induced cleavage of $\mathrm{K} 15$ and $\mathrm{K} 17$ produced at least three fragments of each protein. Caulin et $\mathrm{al}^{14}$ predicted that $\mathrm{K} 15$ and $\mathrm{K} 17$ should be cleaved in the same region as $\mathrm{K} 18$ because all three keratin type I proteins show the same caspase recognition site VEXD at the same position. To determine the exact caspase recognition sites, we used mass spectrometric techniques. For protein identification by electrospray mass spectrometry (ESI-MS) a weak Coomassie Blue-stained spot is sufficient. Spots P1-P6 were digested in the gel with trypsin that cleaves specifically behind arginine and lysine residues. After extraction of the tryptic peptides from the gel matrix and desalting, the peptides were applied to ESI-MS. We screened the spectra for masses 
A

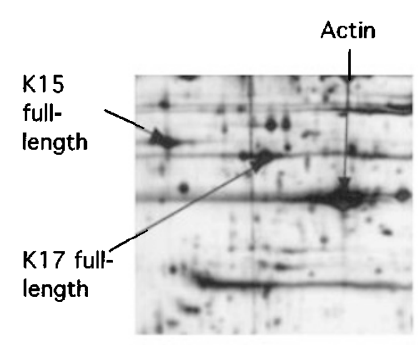

DMSO

B

I

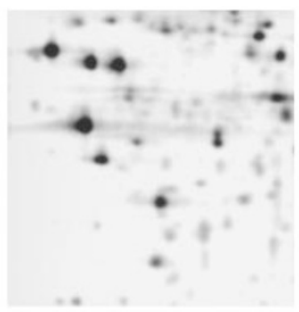

DMSO

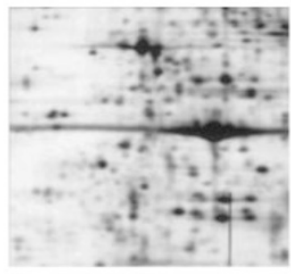

STS (flo)

II

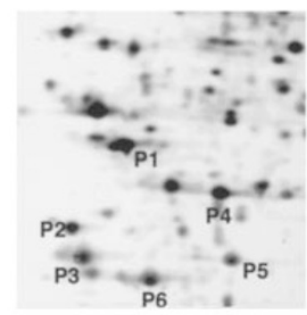

STS (flo)

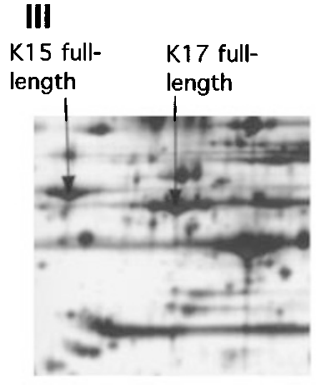

STS + zDEVDfmk

III

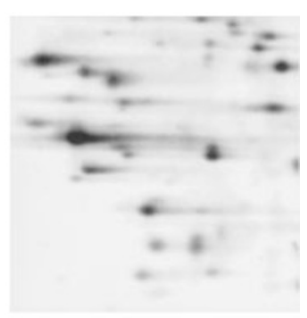

STS + zDEVDfmk

Figure 2 (A) Enlargement of region A (see Figure 1) of (I) non-apoptotic cells (DMSO), (II) apoptotic floating cells (STS flo), and (III) apoptotic cells treated with caspase inhibitor Z-DEVD-fmk (100 $\mu \mathrm{M})$ before induction of apoptosis. (B) Enlargement of region B (see Figure 1) of non-apoptotic cells (I), apoptotic floating cells (II) and apoptotic cells treated with caspase inhibitor Z-DEVD-fmk (III). P1-P6 represent spots of proteolytic fragments of keratin 15 (P1, P2, and P3) and keratin 17 (P4, P5, and P6)

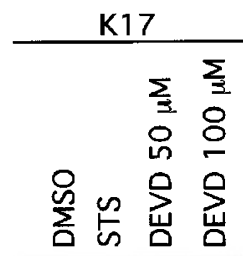

$\mathrm{kDa}$

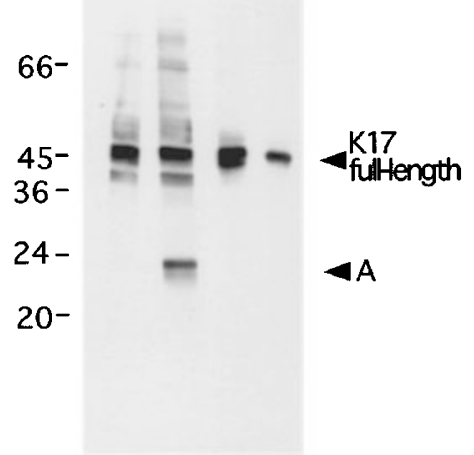

Figure 3 Analysis of keratin 17 proteolysis by Western blotting. Apoptosis of H184A1 cells was induced with $1 \mu \mathrm{M}$ staurosporine (STS) for $15 \mathrm{~h}$. Control cells were incubated with $0.2 \%$ DMSO for the same time. Caspase inhibition was performed by application of the inhibitor Z-DEVD-fmk in indicated concentration. Total cell lysates were separated by $12.5 \%$ SDS-PAGE. After electrophoresis, proteins were transferred onto nitrocellulose membrane and incubated with monoclonal antibodies to keratin 17

that could only be derived from peptides that were cleaved by caspases, which cleave after an aspartic acid only. Tables 1

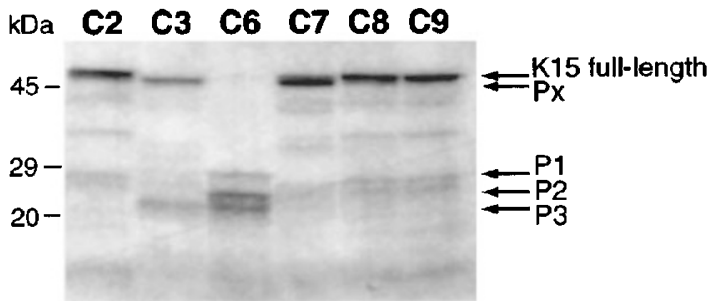

Figure 4 In vitro cleavage of keratin 15 with recombinant caspases. Radioactive labeled K15 was obtained by using a coupled transcription/ translation reticulocyte system in the presence of ${ }^{35} \mathrm{~S}$-methionine. Cleavage reactions were performed with recombinant caspases-2, $-3,-6,-7,-8$ and -9

and 2 list all peptides found by MS. In the tryptic digest of K15 spot P3 we observed a signal with a mass that corresponded to the seqeunce of peptide T1 (Table 1). Sequencing by MS/ MS confirmed that this signal belongs to a peptide with the sequence ${ }^{265}$ AAPGVDLTR ${ }^{273}$ (MS/MS spectrum not shown). Preceding this sequence is the caspase recognition sequence VEMD ${ }^{264}$ indicating that $D^{264}$ is indeed the cleavage site for caspases in K15 during apoptosis. This cleavage site lies in the center of K15. Identified tryptic peptides revealed that fragment P3 is derived from the $\mathrm{C}$ terminal half while fragments $\mathrm{P} 1$ and $\mathrm{P} 2$ are derived from the $\mathrm{N}$-terminal half of K15 (see Table 1). The location in the 2-DE gel suggests that fragment P2 is considerably shorter than P1. This fact allows the prediction of a second caspase cleavage site $\mathrm{N}$-terminal to $\mathrm{D}^{264}$. However, the exact location of this cleavage site could not be determined. The same procedure 
Table 1 Sequences of tryptic peptides after in-gel digestion with trypsin that were identified by tandem mass spectrometry of spots P1, P2 and P3 of keratin 15

\begin{tabular}{|c|c|c|}
\hline $\begin{array}{l}\text { Frag- } \\
\text { ment }\end{array}$ & Position & Amino acid sequence \\
\hline \multicolumn{3}{|l|}{$\mathrm{P1}$} \\
\hline T1 & $1-19$ & MTTTFLQTSSSTFGGGSTR>G \\
\hline T2 & $20-42$ & $\mathrm{R}<\mathrm{GGSLLAGGGGFGGGSLSGGGGSR}>\mathrm{S}$ \\
\hline T3 & $43-50$ & $\mathrm{R}<\mathrm{SISASSAR}>\mathrm{F}$ \\
\hline T4 & $51-65$ & $\mathrm{R}<\mathrm{FVSSGSGGGYGGGMR>V}$ \\
\hline T5 & $107-115$ & $\mathrm{~K}<\mathrm{ITMQNLNDR}>\mathrm{L}$ \\
\hline T6 & $125-136$ & $\mathrm{R}<\mathrm{ALEEANADLEVK}>\mathrm{I}$ \\
\hline $\mathrm{T} 7$ & $137-143$ & $\mathrm{~K}<\mathrm{IHDWYQK}>\mathrm{Q}$ \\
\hline T8 & $159-164$ & $\mathrm{~K}<\mathrm{TIEELR}>\mathrm{D}$ \\
\hline T9 & $167-176$ & $\mathrm{~K}<\mathrm{IMATTIDNSR}>\mathrm{V}$ \\
\hline T10 & $177-185$ & $\mathrm{R}<\mathrm{VILEIDNAR}>\mathrm{L}$ \\
\hline $\mathrm{T} 11$ & $186-192$ & $\mathrm{R}<\mathrm{LAADDFR}>\mathrm{L}$ \\
\hline T12 & $195-202$ & $\mathrm{~K}<\mathrm{YENELALR}>\mathrm{Q}$ \\
\hline $\mathrm{T} 13$ & $203-213$ & $R<Q G V E A D I N G L R>R$ \\
\hline T14 & $215-223$ & $\mathrm{R}<\mathrm{VLDELTLAR}>\mathrm{T}$ \\
\hline $\mathrm{T} 15$ & $243-249$ & $\mathrm{~K}<\mathrm{NHEEEMK}>\mathrm{E}$ \\
\hline \multicolumn{3}{|l|}{$\mathrm{P} 2$} \\
\hline T1 & $107-115$ & $\mathrm{~K}<\mathrm{ITMQNLNDR}>\mathrm{L}$ \\
\hline $\mathrm{T} 2$ & $125-136$ & $\mathrm{R}<\mathrm{ALEEANADLEVK}>\mathrm{I}$ \\
\hline T3 & $137-143$ & $\mathrm{~K}<\mathrm{IHDWYQK}>\mathrm{Q}$ \\
\hline $\mathrm{T} 4$ & $167-176$ & $\mathrm{~K}<$ IMATTIDNSR $>\mathrm{V}$ \\
\hline T5 & $177-185$ & $\mathrm{R}<\mathrm{VILEIDNAR}>\mathrm{L}$ \\
\hline T6 & $186-192$ & $\mathrm{R}<\mathrm{LAADDFR}>\mathrm{L}$ \\
\hline $\mathrm{T} 7$ & $195-202$ & $\mathrm{~K}<\mathrm{YENELALR}>\mathrm{Q}$ \\
\hline T8 & $215-223$ & $\mathrm{R}<\mathrm{VLDELTLAR}>\mathrm{T}$ \\
\hline \multicolumn{3}{|r|}{ 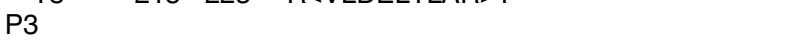 } \\
\hline T1 & $265-273$ & $\mathbf{D}<$ AAPGVDLTR $>$ V \\
\hline $\mathrm{T} 2$ & $274-288$ & $\mathrm{R}<\mathrm{VLAEMREQYEAMAEK}>\mathrm{N}$ \\
\hline T3 & $320-326$ & $\mathrm{~K}<\mathrm{TEITDLR}>\mathrm{R}$ \\
\hline $\mathrm{T} 4$ & $344-356$ & $\mathrm{~K}<\mathrm{AGLENSLAETECR}>\mathrm{Y}$ \\
\hline T5 & $399-407$ & $R<L E Q E I A T Y R>S$ \\
\hline T6 & $408-416$ & $\mathrm{R}<\mathrm{SLLEGQDAK}>\mathrm{M}$ \\
\hline
\end{tabular}

Bold letters indicate caspase cleavage sites. The peptides are also represented as black bars $\mathrm{T} 1-\mathrm{T} 15$ in Figure $5 \mathrm{~A}$. Amino acid sequences were compared using the Swiss-Prot database

was applied for K17 spot P6. In this case we found a peptide with the sequence ${ }^{242}$ AAPGVDLSR ${ }^{250}$ (T1 of P6, Table 2$)$ that confirmed caspase-mediated cleavage after the tetrapeptide VEMD $^{241}$. Furthermore, the sequence ${ }^{409}$ TIVEEVQD $^{416}$ (T9 of P6, Table 2) was identified in the same digest and verified the second cleavage site in K17 at the position EVQD ${ }^{416}$. In the digest of $\mathrm{K} 17$ spot $\mathrm{P} 5$ we found the tryptic fragment ${ }^{409}$ TIVEEVQDGK ${ }^{418}$ (T9 of P5, Table 2 ) which indicated that no cleavage occurred at position $\mathrm{D}^{416}$ in this fragment. The cleavage site at position $D^{241}$ (T1 of P5, Table 2) was also found in P5.

\section{Discussion}

In order to characterize mechanisms leading to morphological changes in epithelial cells after induction of apoptosis we performed two-dimensional gel electrophoresis. We observed the disappearance of full-length keratins 15 and 17 in apoptotic cells and in parallel the appearance of six new fragments of these proteins suggesting a cleavage of K15 and $\mathrm{K} 17$ during apoptosis. Treatment of the cells with the specific inhibitor for caspase-3-like proteases Z-DEVD-fmk prior to the induction of apoptosis blocked the fragmentation of K15 and
Table 2 Sequences of tryptic peptides after in-gel digestion with trypsin that were identified by tandem mass spectrometry of spots P4, P5 and P6 of keratin

\begin{tabular}{|c|c|c|}
\hline Fragment & Position & Amino acid sequence \\
\hline \multicolumn{3}{|l|}{ P4 } \\
\hline T1 & $85-93$ & $\mathrm{~K}<\mathrm{ATMQNLNDR}>\mathrm{L}$ \\
\hline $\mathrm{T} 2$ & $94-100$ & $\mathrm{R}<\mathrm{LASYLDK}>\mathrm{V}$ \\
\hline T3 & $103-114$ & $\mathrm{R}<\mathrm{ALEEANTELEVK}>\mathrm{I}$ \\
\hline $\mathrm{T} 4$ & $129-135$ & $\mathrm{R}<\mathrm{DYSQYYR}>\mathrm{T}$ \\
\hline T5 & $136-143$ & $\mathrm{R}<\mathrm{TIEELQNK}>\mathrm{I}$ \\
\hline T6 & $163-169$ & $\mathrm{R}<\mathrm{LAADDFR}>\mathrm{T}$ \\
\hline T7 & $180-190$ & $\mathrm{R}<\mathrm{LSVEADINGLR}>\mathrm{R}$ \\
\hline T8 & $192-200$ & $\mathrm{R}<\mathrm{VLDELTLAR}>\mathrm{A}$ \\
\hline T9 & $201-211$ & $\mathrm{R}<\mathrm{ADLEMQIENLK}>\mathrm{E}$ \\
\hline T10 & $220-229$ & $\mathrm{~K}<\mathrm{NHEEEMNALR>G}$ \\
\hline \multicolumn{3}{|r|}{ 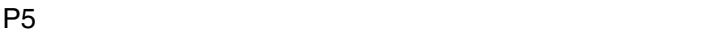 } \\
\hline T1 & $242-259$ & D<AAPGVDLSR $>$ I \\
\hline T2 & $269-277$ & $\mathrm{~K}<\mathrm{DAEDWFFSK}>\mathrm{T}$ \\
\hline T3 & $284-296$ & R<EVATNSELVQSGK >S \\
\hline T4 & $297-303$ & $\mathrm{~K}<\mathrm{SEISELR}>\mathrm{R}$ \\
\hline T5 & $321-333$ & $\mathrm{~K}<\mathrm{ASLEGNLAETENR}>\mathrm{Y}$ \\
\hline T6 & $368-373$ & K<ILLDVK $>$ \\
\hline T7 & $376-384$ & $\mathrm{R}<\mathrm{LEQEIATYR}>\mathrm{R}$ \\
\hline T8 & $386-398$ & R<LLEGEDAHLTQYK>K \\
\hline T9 & $409-418$ & R<TIVEEVQDGK>V \\
\hline \multicolumn{3}{|r|}{ 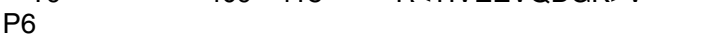 } \\
\hline $\mathrm{T} 1$ & $242-259$ & D<AAPGVDLSR>I \\
\hline $\mathrm{T} 2$ & $269-277$ & $\mathrm{~K}<\mathrm{DAEDWFFSK}>\mathrm{T}$ \\
\hline T3 & $284-296$ & R<EVATNSELVQSGK>S \\
\hline $\mathrm{T} 4$ & $297-303$ & $\mathrm{~K}<\mathrm{SEISELR}>\mathrm{R}$ \\
\hline T5 & $321-333$ & $\mathrm{~K}<\mathrm{ASLEGNLAETENR}>\mathrm{Y}$ \\
\hline T6 & $357-367$ & $\mathrm{R}<\mathrm{CEMEQQNQEYK>I}$ \\
\hline T7 & $376-384$ & R<LEQEIATYR>R \\
\hline T8 & $386-398$ & $\mathrm{R}<\mathrm{LLEGEDAHLTQYK}>\mathrm{K}$ \\
\hline T9 & $409-416$ & $\mathrm{R}<$ TIVEEVQD>G \\
\hline
\end{tabular}

Bold letters indicate caspase cleavage sites. The peptides are also represented as black bars $\mathrm{T} 1-\mathrm{T} 10$ in Figure $5 \mathrm{~B}$. Amino acid sequences were compared using the Swiss-Prot database

$\mathrm{K} 17$ as shown by the complete absence of all cleavage products and in addition the stable appearance of the fulllength $\mathrm{K} 15$ and $\mathrm{K} 17$ in the two-dimensional gel electrophoresis for K17. This observation was supported by Western blot analysis with cells treated with the caspase inhibitors ZDEVD-fmk. These results suggested that caspases are responsible for the cleavage of $\mathrm{K} 15$ and $\mathrm{K} 17$. Besides STS treatment a different apoptotic stimulus termed anoikis resulted in the same fragmentation pattern (data not shown). MS and MS/MS analysis of these spots revealed that three fragments were derived from $\mathrm{K} 15$ and three from $\mathrm{K} 17$ which allowed the conclusion that both proteins contain at least two caspase cleavage sites. All fragments showed nearly the same intensity after silver staining indicating that cleavage at both sites occurred with similar efficiency and that all fragments were comparably stable.

The identification of the cleavage sites in $\mathrm{K} 15$ and $\mathrm{K} 17$ revealed that caspases cleaved $\mathrm{K} 15$ and $\mathrm{K} 17$ at the consensus sequence VEMD/A that is located in the non- $\alpha$ helical linker region $L 1-2$ of the rod domain (Figure $5 A, B$ ). Furthermore, a second cleavage site was found in the tail domain of $\mathrm{K} 17$ at the sequence EVQD/G. A second cleavage site in $\mathrm{K} 15$ was assumed to be in the $\mathrm{C}$ terminal region at position $D^{445}$ with the sequence ESVD/G similar to $\mathrm{K} 17$. This assumption was confirmed by the in vitro 
A $\mathrm{K} 15$

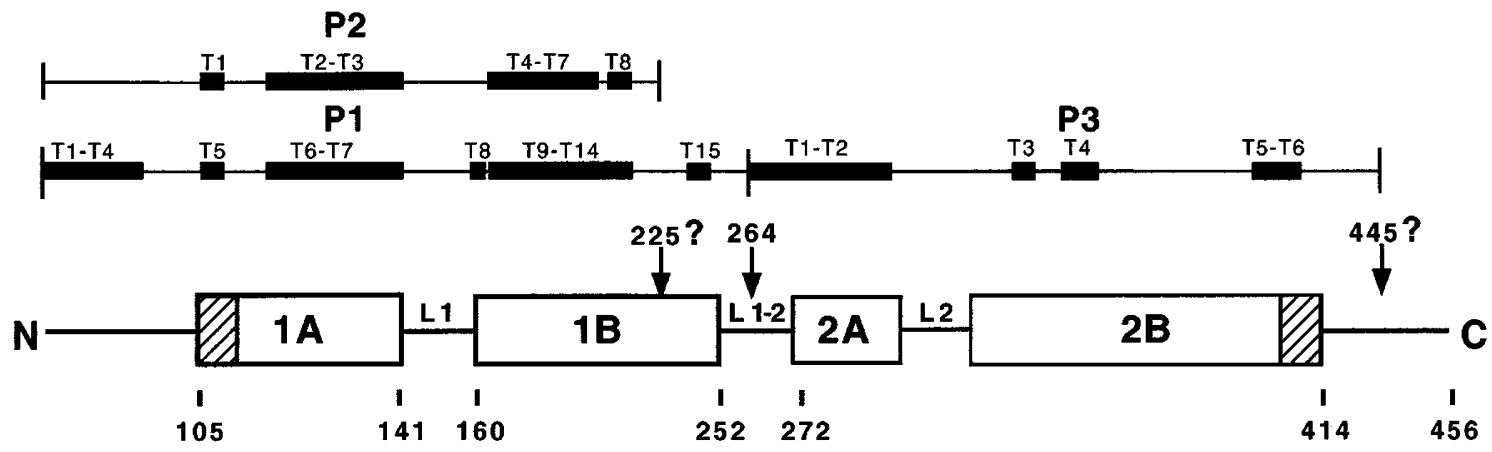

B $\quad \mathrm{K} 17$

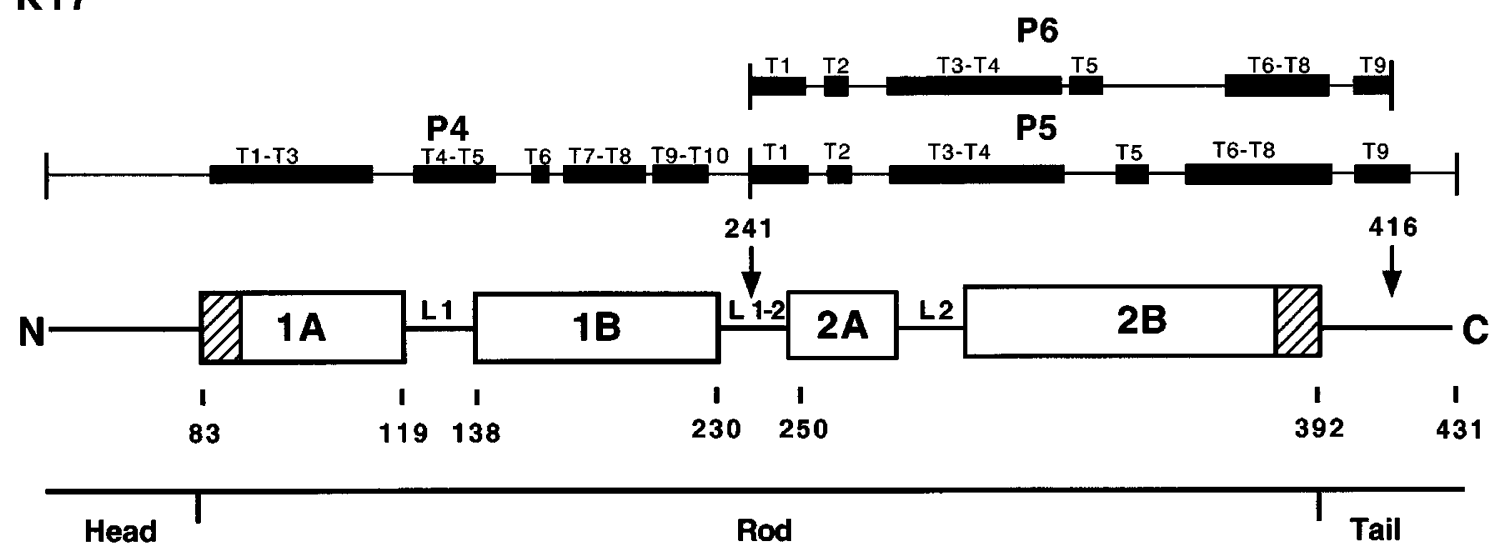

Figure 5 Schematic diagram of keratins 15 and 17 . The rod domain is composed of the $\alpha$-helical subdomains $(1 \mathrm{~A}, 1 \mathrm{~B}, 2 \mathrm{~A}$, and $2 \mathrm{~B})$ that are connected by nonhelical linker regions (L1, L1-2, and L2). The rod domain is flanked by a non-helical $\mathrm{N}$-terminal head and a C-terminal tail domain. The hatched areas mark highly conserved regions of intermediate filament proteins. Arrows indicate caspase cleavage sites and P1 - P6 the resulting proteolytic fragments. Black areas marked at $\mathrm{T} 1-\mathrm{T} 15$ indicate internally sequenced peptides after in-gel digest with trypsin

cleavage experiment of K15. Cleavage by caspases-3 and -7 led to the loss of a small fragment Px from K15 (Figure 4). Figure 5 shows a schematic overview of the cleavage sites and resulting fragments. MS/MS experiments revealed that fragment P1 starts with the first amino acid of $\mathrm{K} 15$ and ends at the caspase cleavage site at position $D^{264}$ (Figure $5 \mathrm{~A})$. Fragment $\mathrm{P} 2$ originates from the $\mathrm{N}$-terminus as $\mathrm{P} 1$ but is significantly shorter than $\mathrm{P} 1$ according to the relative positions of both fragments in the 2-DE gel. Therefore, we assume a third caspase cleavage site at position $D^{225}$ with the sequence ARTD/L that is also in coincidence with the observed relative molecular masses of $\mathrm{P} 1, \mathrm{P} 2$, and $\mathrm{P} 3$ on the 2-DE gel. Figure 5B displays the results for keratin 17. The largest $\mathrm{K} 17$ fragment is $\mathrm{P} 4$ with a molecular mass of $25.9 \mathrm{kDa}$ and 242 amino acids including the $\mathrm{N}$-terminal half of K17. Fragments P5 and P6 derived from the C-terminus but P6 is slightly shorter as P5 according to the second caspase cleavage site in the tail domain at position $\mathrm{D}^{416}$.

The VEMD caspase recognition sequence in the linker L1-2 region is also found in keratins 13, 14 and 16, however, their cleavage during apoptosis could not be experimentally determined until now. ${ }^{22}$ The caspase cleavage motifs VEMD (K13, K14, K15, K16, K17), VEVD (K18, K19, lamin B1, and lamin B2) and VEID (lamins A and C) are well conserved in the L1-2 subdomain of types I and $\mathrm{V}$ intermediate filaments implying that this is an important structural feature. Type II keratins $(\mathrm{K} 1-8)$ do not contain a similar sequence motif, and they do not seem to be cleaved during apoptosis. A common feature of these recognition sites is the amino acid homology in $\mathrm{P} 1, \mathrm{P} 3$, and $\mathrm{P} 4$ positions. The variability in the P2 position of valine for methionine and isoleucine, respectively, is negligibly small. Keratin 15 is recognized by caspases-3, -6 , and -7 but with different specificities (see Figure 4). Caspases-3 and -7 remove the small fragment Px presumably by cleavage at position $D^{445}$ with the sequence ESVD/G. The VEMD/A sequence motif is recognized by caspase- 6 while caspases-3 and -7 show only minor activity, if at all. This observation is consistent with the preference of caspase- 6 for amino acids with aliphatic side chains in the P4 position, while caspases -3 and -7 prefer amino acids with acidic side chains. $^{23}$ The second identified cleavage site in $\mathrm{K} 17$ has the sequence EVQD and should therefore be preferred by caspases-3 or -7. Keratins form the intermediate filament cytoskeleton of epithelial cells and constitute nearly $5 \%$ of total cellular protein. Their tendency to form heterodimers made of types I and II in a 1:1 molar ratio make keratins unique among IF proteins. According to the physical 
requirements of each epithelial cell type, these heterodimers are specifically expressed. Although the biological relevance of human keratin fragmentation during apoptosis remains to be determined, proteolysis of the highly insoluble keratins may facilitate the disposal of apoptotic epithelial cells by phagocytosis. Truncation or point mutation experiments of IF proteins revealed that one function of IF proteins is to provide mechanical integrity to cells. Without a proper IF network, cells become fragile and prone to breakage upon mechanical stress. Especially point mutations in the highly conserved amino terminus of Helix $1 \mathrm{~A}$ or the carboxy terminus of $2 \mathrm{~B}$ (see Figure 5) can contribute to the disorganization of IF stucture. ${ }^{24}$ This suggests that sequence conservation at these sites is crucial for the ideal arrangement of the proteins assembling the filament network. On the other hand point mutations in the center of the rod domain or the linker regions have no detectable effect on IF aggregation. ${ }^{2}$ For example, systematical mutations of the non-helical linker L1-2 subdomain in keratin 14 made in such a manner that this region becomes completely $\alpha$-helical had no severe influence on keratin filament assembly in vitro. ${ }^{25}$ These findings show that additional experiments will be needed to understand the function of the highly flexible linker L1-2 subdomain. Caspase-mediated cleavage at this site however seems to represent an effective mechanism to disrupt the network of several IF proteins, namely, lamins A, B, and C, keratins $15,17,18$, and 19 , and vimentin. This part of the cell death process may support condensation and packing of the cell contents into apoptotic bodies and thereby facilitating phagocytosis of the apoptotic cells by other cells. However, there is evidence for more than a solely mechanical function of keratins. Caulin et al. ${ }^{26}$ could show that decreasing levels of $\mathrm{K} 8$ and $\mathrm{K} 18$ increase the sensitivity of cultured epithelial cells towards tumor necrosis factor (TNF) mediated apoptosis. By binding to the cytoplasmic domain of TNFR2, $\mathrm{K} 8$ and $\mathrm{K} 18$ modulate the TNF-dependent activation of JNK and the transcription factor $\mathrm{NF}_{\kappa} \mathrm{B} .^{26}$

\section{Materials and Methods}

\section{Cell culture and induction of apoptosis}

The human breast epithelial cell line H184A1 was cultured in DMEM HAMs F12 (Biochrom, Berlin, Germany) supplemented with $5 \%$ fetal calf serum (Life Technologies, Karlsruhe, Germany), $10 \mu \mathrm{g} / \mathrm{ml}$ insulin (Biochrom), $10 \mu \mathrm{g} / \mathrm{ml}$ transferrin (Life Technologies), $1.8 \mu \mathrm{g} / \mathrm{ml}$ hydrocortisol and $100 \mathrm{U} / \mathrm{ml}$ penicillin and $100 \mu \mathrm{g}$ streptomycin. Apoptosis was induced by incubating $80 \%$ confluent cells in medium containing $1 \mu \mathrm{M}$ staurosporine (STS) (Sigma) for up to $18 \mathrm{~h}$. Cells in suspension and adherent cells were collected separately. The rate of apoptotic cells was determined with APOBRDU $^{T M}$ kit (Pharmingen, Hamburg, Germany) by nick-end labeling of single- and double-strand DNA breaks with BrdUTP by terminal transferase. Eighty-nine per cent of cells in suspension were found to be apoptotic. Z-DEVD-fmk $(100 \mu \mathrm{M})$ an inhibitor for caspase-3like proteases was purchased from Calbiochem (Bad Soden, Germany).

\section{Sample preparation for 2-DE}

Adherent cells were harvested by scraping, detached cells by centrifugation of the culture medium. Cells were washed twice with PBS containing a protease inhibitor cocktail (Complete, Boehringer) and the cell pellets were snap frozen in liquid nitrogen and stored at $-80^{\circ} \mathrm{C}$. The cell pellets were thawed and during this procedure rapidly mixed with urea (7 M final concentration), thiourea (2 M final concentration), DTT (70 mM final concentration), 4\% CHAPS, and with protease inhibitor solutions. The final concentration of protease inhibitors, salts and buffers in the protein sample was $1.4 \mu \mathrm{M}$ pepstatin A, $1 \mathrm{mM}$ PMSF, $1 \mathrm{mM}$ benzamidine, $2.1 \mu \mathrm{M}$ leupeptin, $1 \mathrm{mM}$ EDTA, $1 \mathrm{mM} \mathrm{KCl}$ and $40 \mathrm{mM}$ Tris/ $\mathrm{HCl}$. Finally $2.5 \%$ carrier ampholytes were added (Servalyt $\mathrm{pH} 2-4$, Serva, Heidelberg, Germany). After $30 \mathrm{~min}$ of gentle stirring at room temperature, the samples were centrifuged at $100000 \times g$ for $20 \mathrm{~min}$. The supernatant was frozen at $-80^{\circ} \mathrm{C}^{19,27}$

\section{Two-dimensional gel electrophoresis (2-DE)}

2-DE was performed by the combination of isoelectric focusing (first dimension) and SDS-PAGE (second dimension) as developed by Klose and Kobalz. ${ }^{19}$ Analytical gels for protein pattern comparison had a gel size of $30 \times 23 \times 0.075 \mathrm{~cm}$, micropreparative gels for protein identification had a gel size of $30 \times 23 \times 0.15 \mathrm{~cm}$. All gel solutions and 2-DE equipment were purchased from WITA GmbH (Teltow, Germany). Isoelectric focusing (IEF) was performed in rod gels (inner diameter analytical gels: $0.09 \mathrm{~cm}$ and micropreparative gels $0.15 \mathrm{~cm}$, respectively). $10-12 \mu \mathrm{l}$ of the samples were loaded at the anodic side on an analytical gel, and $45-55 \mu$ l onto a micropreparative gel and focused in a vertical IEF chamber without cooling. After isoelectric focusing, the gels were equilibrated for $10 \mathrm{~min}$ in a buffer containing $1 \mathrm{M}$ Tris, $40 \%$ glycerol, $70 \mathrm{mM}$ DTT, and $3 \%$ SDS. The second-dimensional separation was done by a vertical $15 \%$ SDSPAGE gel according to Laemmli. ${ }^{28}$ The stacking gel was replaced by the IEF gel of the first dimension. For analytical gels, the proteins were silver-stained based on the procedure of Klose and Kobalz. ${ }^{19}$ For micropreparative gels, they were stained by Coomassie Blue described by Eckerskorn et al. ${ }^{29}$ or by colloidal Commassie Blue according Neuhoff et al. ${ }^{30}$

\section{In-gel digestion and mass spectrometry}

One Coomassie Blue-stained protein spot of a micropreparative gel was sufficient for an unambiguously protein identification. Excised gel spots were diced and washed $1 \mathrm{~h}$ in $100 \mu \mathrm{l}$ of $100 \mathrm{mM}$ ammonium hydrogen carbonate. Gel slices were destained with $100 \mu \mathrm{l} 50 \%$ acetonitrile/100 $\mathrm{mM}$ ammonium hydrogen carbonate by shaking for $1 \mathrm{~h}$. Fifty $\mu \mathrm{l}$ of acetonitrile were added to shrink the gel pieces. After 5-10 min the solvent was removed and the gel pieces were vacuumdried in a Speed Vac (10-15 min). The gel slices were soaked with $10 \mu \mathrm{l}$ of $25 \mathrm{mM}$ ammonium hydrogen carbonate containing $0.3-0.5 \mu \mathrm{g}$ modified trypsin (Boehringer Mannheim, Germany). After 10-15 min, $20-30 \mu$ l of additional buffer were added to cover the gel pieces. The digestion was performed overnight at $37^{\circ} \mathrm{C}$. After digestion the supernatant was acidified with $10 \%$ TFA to a final concentration of $1 \%$ TFA and shaken for $1 \mathrm{~h}$ at $60^{\circ} \mathrm{C}$. The supernatant from the last step was saved in a new tube. The peptides were extracted twice with $60 \%$ acetonitrile $/ 0.1 \%$ TFA for $30 \mathrm{~min}$ at $60^{\circ} \mathrm{C}$. All supernatants were combined and dried in a Speed Vac. For ESI-MS the peptides were reconstituted in $20 \mu \mathrm{l} 0.1 \%$ TFA and desalted by ZipTips (Millipore, Eschborn, Germany). The peptides were eluted from ZipTips with $3 \mu \mathrm{l}$ $50 \% \mathrm{MeOH}, 1 \%$ formic acid. 
ESI-MS/MS experiments were performed with a Q-Tof (Micromass, Manchester, UK) equipped with a nanoflow Z-spray ion source. A potential of $1.4 \mathrm{kV}$ was applied to the nanoflow borosilicate glass capillary (Micromass, Manchester, UK) containing $1 \mu \mathrm{l}$ of the peptide mixture. An aliquot of $1 \mu \mathrm{l}$ was sufficient for one MS spectrum and five to six MS/MS experiments, with a flow rate of $30 \mathrm{nl} / \mathrm{min}$. The Q-Tof calibration was performed with [Glu]-fibrinopeptide (Sigma, Deisenhoven, Germany). For protein search fragment masses of MS/MS spectra were matched with the theoretical fragment masses of all human proteins of the Swiss-Prot database using internet search tools MS-Tag: http://falcon.ludwig.ucl.ac.uk/ucsfhtml3.2/mstagfd.htm.

\section{Immunoblotting}

Immunoblotting was essentially done as described. ${ }^{31}$ Cells were lysed by boiling in $10 \mathrm{mM}$ Tris- $\mathrm{HCl}$, pH 7.5, 2 mM EDTA, 1\% SDS, and $30-$ $50 \mu \mathrm{g}$ protein was separated by SDS-PAGE and transferred to nitrocellulose membrane (Schleicher \& Schuell, Dassel, Germany). Monoclonal anti-keratin 17 antibody was diluted 1:400. HRPconjugated secondary anti-mouse antibody (Promega, Mannheim, Germany) was diluted $1: 10000$. Proteins were visualized by detecting the peroxidase activity using the ECL-system (Amersham, Braunschweig, Germany). Monoclonal anti-keratin 17 antibody (Clone CK-E3) was purchased by Sigma.

\section{In vitro cleavage of keratin 15 with recombinant caspases}

Cleavage reactions with recombinant caspases-2, $-3,-6,-7,-8$ or -9 (Pharmingen) were performed in $20 \mu \mathrm{l}$ caspase-buffer $(50 \mathrm{mM}$ HEPES, pH 7.4, 0.1\% CHAPS, $5 \mathrm{mM}$ DTT, $1 \mathrm{mM}$ PMSF, $50 \mu \mathrm{M}$ leupeptin, $200 \mu \mathrm{g} / \mathrm{ml}$ aprotinin) at $30^{\circ} \mathrm{C}$ for $3 \mathrm{~h}$ using keratin 15 as substrate which was transcribed from the pKH15-3 clone (a kind gift from R Leube, Mainz, Germany) and translated using the TNT reticulocyte system (Promega) with the T7 polymerase in the presence of ${ }^{35} \mathrm{~S}$-methionine. Five $\mu$ l of the translation mixture was used for the cleaving reaction with the recombinant caspases described above. Samples were separated by $15 \%$ SDS-PAGE. ${ }^{35}$ S-labeled proteins were detected by autoradiography after enhancement with amplifier solution (Amersham).

\section{Acknowledgements}

We would like to thank Rudolf Leube for the CK15 plasmid, and Ina Krukenberg for excellent technical assistance. This work was supported in part by a grant of the Deutsche Forschungsgemeinschaft SFB 366.

\section{References}

1. Coulombe PA (1993) The cellular and molecular biology of keratins: beginning a new era. Curr. Opin. Cell Biol. 5: 17-29

2. Fuchs E and Weber K (1994) Intermediate filaments: structure, dynamics, function, and disease. Annu. Rev. Biochem. 63: 345-382

3. Houseweart MK and Cleveland DW (1998) Intermediate filaments and their associated proteins: multiple dynamic personalities. Curr. Opin. Cell Biol. 10: 93-101

4. Klymkowsky MW (1996) Intermediate filaments as dynamic structures. Cancer Metastasis Rev. 15: 417-428

5. CelebiJT, Tanzi EL, Yao YJ, MichaelEJ and Peacocke M(1999) Mutation report: identification of a germline mutation in keratin 17 in a family with pachyonychia congenita type 2. J. Invest. Dermatol. 113: 848-850
6. Covello SP, Smith FJ, Sillevis Smitt JH, Paller AS, Munro CS, Jonkman MF, Uitto $\mathrm{J}$ and McLean WH (1998) Keratin 17 mutations cause either steatocystoma multiplex or pachyonychia congenita type 2. Br. J. Dermatol. 139: 475-480

7. Waseem A, Dogan B, Tidman N, Alam Y, Purkis P, Jackson S, Lalli A, Machesney $M$ and Leigh IM (1999) Keratin 15 expression in stratified epithelia: downregulation in activated keratinocytes. J. Invest. Dermatol. 112: 362-369

8. Jih DM, Lyle S, Elenitsas R, Elder DE and Cotsarelis G (1999) Cytokeratin 15 expression in trichoepitheliomas and a subset of basal cell carcinomas suggests they originate from hair follicle stem cells. J. Cutan. Pathol. 26: 113-118

9. Kanitakis J, Bourchany D, Faure M and Claudy A (1999) Expression of the hair stem cell-specific keratin 15 in pilar tumors of the skin. Eur. J. Dermatol. 9: 363 365

10. Franzen B, Linder S, Alaiya AA, Eriksson E, Uruy K, Hirano T, Okuzawa K and Auer $G$ (1996). Analysis of polypeptide expression in benign and malignant human breast lesions: down-regulation of cytokeratins. Br. J. Cancer 74: 1632 1638

11. Frisch SM and Ruoslahti E (1997) Integrins and anoikis. Curr. Opin. Cell Biol. 9: 701-706

12. Cardone MH, Salvesen GS, Widmann C, Johnson G and Frisch SM (1997). The regulation of anoikis: MEKK-1 activation requires cleavage by caspases. Cell 90: 315-323

13. McGill G, Shimamura A, Bates RC, Savage RE and Fisher DE (1997) Loss of matrix adhesion triggers rapid transformation-selective apoptosis in fibroblasts. J. Cell. Biol. 138: 901-911

14. Caulin C, Salvesen GS and Oshima RG (1997) Caspase cleavage of keratin 18 and reorganisation of intermediate filaments during epithelial cell apoptosis. J. Cell Biol. 138: 1379-1394

15. Ku N-O, Liao J and Omary MB (1997) Apoptosis generates stable fragments of human type I keratins. J. Biol. Chem. 272: 33197-33203

16. MacFarlane M, Merrison W, Dinsdale D and Cohen GM (2000) Active caspases and cleaved cytokeratins are sequestered into cytoplasmic inclusions in TRAILinduced apoptosis. J. Cell Biol. 148: 1239-1254

17. Rao L, Perez D and White E (1996) Lamin proteolysis facilitates nuclear events during apoptosis. J. Cell Biol. 135: 1441-1455

18. Prasad SC, Thraves PJ, Kuettel MR, Srinivasarao GY, Dritschilo A and Soldatenkov VA (1998) Apoptosis-associated proteolysis of vimentin in human prostate epithelial tumor cells. Biochem. Biophys. Res. Commun. 249: 332-338

19. Klose $\mathrm{J}$ and Kobalz U (1995) Two-dimensional electrophoresis of proteins: An updated protocol and implications for a functional analysis of the genome. Electrophoresis 16: 1034-1059

20. Muller EC, Schumann M, Rickers A, BommertK, Wittmann-Liebold B and Otto A (1999) Study of Burkitt lymphoma cell line proteins by high resolution twodimensional gel electrophoresis and nanoelectrospray mass spectrometry. Electrophoresis 20: $320-330$

21. Brockstedt E, Rickers A, Kostka S, Laubersheimer A, Dörken B, WittmannLiebold B, Bommert $K$ and Otto A (1998) Identification of apoptosis-associated proteins in a human Burkitt lymphoma cell line. Cleavage of heterogeneous nuclear ribonucleoprotein A1 by caspase 3. J. Biol. Chem. 273: 28057-28064

22. Prasad S, Soldatenkov VA, Srinivasarao G and Dritschilo A (1999) Intermediate filament proteins during carcinogenesis and apoptosis (Review). Int. J. Oncol. 14: $563-570$

23. Nicholson DW and Thornberry NA (1997) Caspases: killer proteases. Trends Biochem. Sci. 22: 299-306

24. Fuchs $E$ (1994) Intermediate filaments and disease: mutations that cripple cell strength. J. Cell Biol. 125: 511-516

25. Letai A, Coulombe PA and Fuchs E (1992) Do the ends justify the mean? Proline mutations at the ends of the keratin coiled-coil rod segment are more disruptive than internal mutations. J. Cell Biol. 116: 1181-1195

26. Caulin C, Ware CF, Magin TM and Oshima RG (2000) Keratin-dependent, epithelial resistance to tumornecrosis factor-induced apoptosis. J. Cell Biol. 149: $17-22$

27. Otto $A$, Thiede $B$, Müller E-C, Scheler $C$, Wittmann-Liebold $W$ and Jungblut $P$ (1996) Identification of human myocardial proteins separated by twodimensional electrophoresis using an effective sample preparation for mass spectrometry. Electrophoresis 17: 1643-1650

28. Laemmli UK (1970) Cleavage of structural proteins during the assembly of the head of bacteriophage T4. Nature 227: 680-685 
29. Eckerskorn C, Jungblut P, Mewes W, Klose J and Lottspeich F (1988) Identification of mouse brain proteins after two-dimensional electrophoresis and electroblotting by microsequence analysis and amino acid composition analysis. Electrophoresis. 9: 830-838

30. Neuhoff V, Arold N, Taube Dand EhrhardtW(1988) Improved staining of proteins in polyacrylamide gels including isoelectric focusing gels with clear background at nanogramm sensitivity using Coomassie Brilliant Blue G-250 and R-250. Electrophoresis 9: 255-262
31. Rickers A, Brockstedt E, Mapara MY, Otto A, Dörken B and Bommert K (1998) Inhibition of CPP32 blocks surface IgM-mediated apoptosis and D4-GDI cleavage in human BL60 Burkitt lymphoma cells. Eur. J. Immunol. 28: 296-304 